\title{
THE BURNOUT SYNDROME OF EDUCATIONAL WORKERS
}

\section{SINDROM SAGOREVANJA NA RADU KOD PROSVETNIH RADNIKA}

\author{
Nada Marić1,2, Nataša Maksimović ${ }^{3}$, Petar Bulat ${ }^{4,5}$
}

\begin{abstract}
${ }^{1}$ Institute of Occupational and Sports Medicine of the Republic of Srpska - Center Bijeljina, Bijeljina, Bosnia and Herzegovina

${ }^{2}$ University of Belgrade, Faculty of Medicine, Belgrade, Serbia - PhD candidate

${ }^{3}$ University of Belgrade, Faculty of Medicine, Institute of Epidemiology, Belgrade, Serbia

${ }^{4}$ University of Belgrade, Faculty of Medicine, Belgrade, Serbia

${ }^{5}$ Serbian Institute of Occupational Health, Belgrade, Serbia
\end{abstract}

Correspondence: petar.bulat@med.bg.ac.rs

Keywords:

occupational stress, burnout syndrome, educational personnel, teachers, working environment

\section{Abstract}

Since the 1970's when it first started being mentioned in scientific literature, the burnout syndrome has become a widely explored phenomenon. It is defined as a stressful reaction at workplace characterized by emotional exhaustion, depersonalization/cynicism and reduced feeling of personal achievements. However, authors agreed that it is a multicausal phenomenon as they identified a large number of situational and individual factors involved in its creation. Situational factors relate to working environment and include characteristics of work and profession itself, so as the way of work organization. On the other hand, individual factors include personality characteristics, sociodemographic characteristics and various life-working attitudes of individuals. However, existence of certain contradictions has been noticed and its variation depending on the country in question. The importance of this phenomenon is reflected in numerous negative effects it leaves on the health of individuals, but also in the significant economic overloading of employer and the country, as well. This is the reason for conducting numerous researches regarding this syndrome, with a high prevalence observed in a wide range of professions, including teachers. Authors emphasize that the importance of researching this phenomenon among teachers is of global interest due to already descripted negative effects on teachers. Additionally, it has a direct effect on educational process, as well as negative influence on mental and emotional growth of children. Consequently, additional research is necessary, especially among teachers, in order to better understand this phenomenon. Gaining further knowledge would enable us to form targeted interventions in order to reduce stress exposure at work and reduce the prevalence of this syndrome among teachers. 


\section{Sažetak}

Od kako je počeo da se pominje u naučnoj literaturi sedamdesetih godina prošlog veka, sindrom sagorevanja na radu do danas je postao široko istraživan fenomen. Reč je o stresogenoj reakciji na radnom mestu koja se karakteriše nastankom emocionalne iscrpljenosti, depersonalizacije/ cinizma i smanjenog osećaja ličnih dostignuća. Autori su se, međutim, složili da je ipak reč o multikauzalnom fenomenu i identifikovali su veliki broj situacionih i individualnih faktora koji učestvuju u njegovom nastanku. Situacioni faktori se odnose na radnu sredinu i obuhvataju karakteristike samog posla i zanimanja, kao i način organizacije rada, dok individualni faktori obuhvataju karakteristike ličnosti, sociodemografske karakteristike i različite životno-radne stavove individua. Uočeno je, ipak, postojanje određenih kontradiktornosti i variranje ovog fenomena od zemlje do zemje. Značaj ovog fenomena je, pre svega, zbog brojnih negativnih efekata koje ostavlja na zdravlje pojedinaca, zatim i zbog značajnog ekonomskog optrećenja poslodavaca, ali i zemlje. Zbog toga su sprovedena brojna istraživanja ovog sindroma i uočena je visoka prevalencija u širokom spektru zanimanja, među kojima su i nastavnici. Autori naglaša-

Ključne reči:

profesionalni stres, sindrom sagorevanja na radu, prosvetni radnici, nastavnici, radna sredina vaju da je istraživanje ovog fenomena među nastavnicima od globalnog interesa jer on, pored već opisanih negativnih efekata kod nastavnika, direktno utiče i na obrazovni proces, kao i da ima negativne uticaje na mentalni i emotivni razvoj dece. Neminovno je da su potrebna dodatna istraživanja, posebno u populaciji nastavnika, da bismo ovaj fenomen mogli bolje da razumemo. Ta znanja bi nam omogućila formiranje ciljanih intervencija u svrhu smanjenja izloženosti stresu na radu i smanjenja prevalencije ovog sindroma među nastavnicima.

\section{Introduction}

The burnout syndrome was mentioned for the first time in scientific literature in the 1970's. It is defined as a stressful reaction at workplace, in literature very often described as syndrome characterized with emotional and physical exhaustion from which individuals are not able to recover. After further development of depersonalization or cynicism, it leads to bad relations at work, between colleagues or clients, and afterwards, towards feeling of low personal achievements due to loss of self-confidence in own abilities. So far, the research on this phenomenon became international $(1,2)$.

The appearance of the burnout syndrome was noticed in wide spectrum of professions. Primarily, it was researched and related to so-called helping professions such as healthcare, social workers, psychotherapy. Its presence was noticed in other professions whereas employees are exposed to high levels of stress, such as pilots, military personnel, police officers, as well as in professions where employees are constantly exposed to constant pressure. It can be related to realization of certain profit and aims (economists, managers), or professions where disproportion between high level of professional responsibility and low salaries is present (kindergarten teachers, teachers, professors etc.) $(1,2)$.

However, due to social significance and great number of employees, the research on this phenomenon among teachers is of global interest which is why numerous researches have already been conducted. It points out the presence of high incidence of this syndrome in profession of teachers and it reflects significant negative effects on the health of individuals such as numerous psychic and physical consequences (3-5). This syndrome also leads to increase of the rate of presentism and absenteeism (5). Consequently, absenteeism directly leads to the loss of teaching classes and its numbers (creating a negative effect on educational process), while presentism manifests through inadequate teaching (while establishing bad teacher-student relationship). Inadequate cooperation and teacher-student relation disrupts children's learning process and their further progress, and can lead to bad social and emotional growth of children as a consequence $(5,6)$.

\section{Prevalence}

Previous research on this syndrome points out an importance of its prevalence. For example, in a study conducted in Lithuania, high level of emotional exhaustion was marked in $25,6 \%$ of teachers, high depersonalization in $10,6 \%$ and low personal achievements in $33,7 \%$ (7). High emotional exhaustion was present in $36 \%$ of cases in Sweden, high depersonalization in $11 \%$ and low achievements in $21 \%$ of cases (8). In other European countries, as well, frequency of the burnout syndrome was significant and ranged between $25-30 \%$ (9). High frequency of this syndrome is also marked in the countries of the world such as Australia, Canada and China (10-13). Contrary to this, research in our region showed different results. In Republic of Srpska, only one relevant research was conducted which showed that teachers are experiencing lower level of burnout. In this research, high emotional exhaustion was found in only $4 \%$ cases, high depersonalization in $2,8 \%$ and low level of personal achievements had only $18 \%$ of teachers. However, the sample in this research is very small, so the results should be taken with reserve (14). Also, results of research in environment showed 
lower prevalence of the burnout syndrome at work of educational workers than in other foreign studies $(15,16)$.

\section{Etiology}

Opinions on etiology of the burnout syndrome are divided. Most authors agree that this is the syndrome of multi causal genesis and there are numerous factors that contribute and affect its occurrence $(1,17)$. Those factors can be divided on situational and individual. Situational factors relate to working environment and include characteristics of work and profession itself, as well as the method of organization of work. On the other hand, individual factors include personality characteristics, sociodemographic characteristics and various life-working attitudes of the individuals $(1,17)$.

\section{Situational factors}

\section{Working environment}

A number of the studies have pointed to the fact that factors of the working environment, apropos professional stress, are very important predictor of the burnout syndrome, and in certain European countries it is considered as professional disease (18-23). Many authors tried to explain relation between stress at work with the burnout syndrome and most often explanation included disproportionate demands expected from workers and resources at his/hers disposal $(18,19)$. In a longer time period, this disproportion, i.e. chronical work stress, leads to the occurrence of symptoms of burnout syndrome and later to the manifestation of the consequences. Thereby, numerous research $(1,22,26)$ pointed out the existence of a strong connection between the burnout syndrome and psychosocial demands at workplace, such as workload, time pressure at work and the presence of conflicting demands. Most often researched factor was job control, i.e. workers autonomy at work place. Job control generally involves two concepts, possibility to learn something new and develop new skills, as well as the ability of individual to affect the content and work methods. It is noticed that the burnout syndrome is most often present in employees who have small possibilities of participation and decision-making regarding content and work methods. However, as a significant factor, social support was included very often as well $(1,20,22,27)$. It entitles adequate cooperation and communication with colleagues and superiors. Other research on burnout syndrome (27) showed that employees could endure even greater psychosocial efforts if they would be adequately rewarded the effort reward model.

\section{Occupation characteristics}

The burnout was also explored from the aspect of profession, so the first studies were focused on so-called helping professions and educational sector, explaining an intensive work in the sense of providing assistance or education which represents great emotional pressure leading to the burnout syndrome. Later, research expanded to the professions that include contact with people and setting up of certain demands, like in the case of managers. Results showed that those so-called "client stressors" are less linked to the burnout syndrome comparing to earlier mentioned demands, i.e. "work stressors" (1). In case of teachers, studies showed there are differences between primary and secondary schools (28), as well as working with older and younger children (8). Studies conducted in Greece (28) point out the fact that there is a bigger risk of burnout growth and that more often teachers who work in primary education are the ones suffering from stress. Authors explained that fact with primary education suffering from lack of reform. Another research conducted in Sweden (8) stated that teachers who work with older children are more exposed to the stress than teachers who work with smaller children. They linked this occurrence with the fact that teachers of lower grades have only one or several classes and their own classroom, while teachers in higher grades have more classes and during their work, they are obliged to change classrooms and the work with older children is more demanding.

\section{Organizational characteristics}

As a significant factor that contributes to the development of the burnout syndrome, organization characteristics could be stated, such as the following: hierarchy and setting up certain aims or job security stand out, as well as shaping of emotional and cognitive relation of people and work (1). In the previous research, for example, during comparison of schools with high and low level of the burnout, they noticed they differ in relation to the value systems, setting educational goals, administrative environment (clearly defined hierarchy, management and the role of teachers) and even the physical environment (cleanliness and spatial planning) (29). This concept is partly under the influence of various social, cultural and economic standards (1). It is precisely the metanalysis of the burnout syndrome among teachers in 36 countries that points to the variation of this phenomenon between the countries and suggests that environmental factors (such as the education system) and the culture should be highly considered during the analysis (4).

\section{Individual characteristics}

\section{Personality characteristics}

Many researchers (17,30-32) asked the question how some persons who work in the same environment like other persons develop the burnout syndrome while others do not. An explanation lies in the fact that some persons who work in the same profession and do the same job, in the same working conditions, have different personalities - which reflects on process of working activities itself, as well as on interpersonal relationships. Various individual 
characteristics were identified as significant predictors of the burnout syndrome. In case of teachers, an influence of the negative affectivity, locus control, type of personality (neuroticism), low self-confidence, low emotional intelligence, as well as an impact of regressive "coping" strategies, i.e. mechanisms according to which a person confronts with stress, have been researched (17,30-33). Research showed that low self- confidence, outer locus control (the belief that people cannot influence their own destiny, that other things are responsible for their fate and they cannot change them), persistence and avoiding mechanism of defense represent typical profile of a person subjected to stress (1).

\section{Socio-demographic characteristics}

In the group of socio-demographic characteristics, most often explored are the following: gender, age and marital status. A number of studies indicate that for females it is more difficult to adapt to stressful conditions and react without emotional exhaustion - all causing the burnout syndrome more common at females $(3,32)$. On the contrary, meta-analysis (35) disapproves these findings and concludes that there is no difference in the perception of the stress at work between men and women. Some authors (36) state that females may be more likely to develop emotional exhaustion, but males are prone to the development of depersonalization. However, it is an interesting fact that gender difference is significantly emphasized in the American population more than in the European (36). It is also assumed that the presence or absence of full equality in the country affects development of the burnout syndrome, and the authors state that it is precisely the representation of the conservative role of women in society that makes women more vulnerable population for development of this disorder (4). Nowadays, research on the burnout syndrome of educational workers points to the existence of the contradictory attitudes about the influence of the age of teachers to the development of this disorder. Results showed that in Germany older teachers are more exhausted $(>50)$, while in China and Greece it is younger population $(<40$ and $<30)(13,34)$. All authors have certain explanations for the results. In the study conducted in German (13) authors assume that in time, older teachers develop more adequate and efficient defense mechanisms for facing constant stress. Different group of authors (37) consider that older teachers maybe do not want to admit and report stressful situations. Opposingly, in studies conducted in China and Greece $(34,38)$ it is emphasized that teachers younger than 30 or 40 are the most vulnerable because in that period they are forming families, and at the same time they are professionally most active so they are torn between various roles and obligations. Additionally, they may be new to the profession, which is the reason why they are intensively developing the burnout. Results have showed that the feeling of personal achievements (37) of married teachers is more significant, and that the divorced teachers are more vulnerable population for developing the burnout syndrome (9).

\section{Life and work attitudes/behavior}

One of the predictors of the burnout syndrome which is also mentioned in the literature is the existence of work-life conflict, respectively, inability to align obligations at work and in private life. This predictor is rarely examined, comparing to the other burnout predictors. It emphasizes that females are more exposed to the conflict between family and business obligations, due to the fact that they take family obligations as its own responsibility, and the conflict which is present in females results in high sensitivity and often development of the burnout syndrome at work $(9,39)$. Also, among certain researchers (1) different expectations are mentioned as an important factor, which are idealistic or unrealistic relating to work, and considered as a potential risk. However, the design of the conducted studies did not allow the establishment of cause-and-effect connections.

\section{Consequences}

The significance of the burnout syndrome lies in its consequences. A number of research $(5,8,40,41)$ pointed out to the fact that this syndrome leaves significant consequences on the health of workers, but also on their working skills. Among them, impairing the mental health of workers in the form of depressive and sleep disorders $(5,8)$, together with the loss of energy, in long-term burnout syndrome leads to the disruption of the physiological functions in the organism, which may result in the objectification of symptoms. Due to that fact, the burnout syndrome relates with increased risk of cardiovascular diseases and risk factors for development of cardiovascular diseases (obesity, hyperlipidemia, type 2 diabetes, metabolic syndrome, hypertension) (5). This syndrome is also connected to gastrointestinal difficulties (5) and musculoskeletal pain (8). Connection between unhealthy pattern of behavior such as alcohol consumption and the burnout syndrome at work was noticed, as well (41). Beside these health consequences, this syndrome has significantly negative impact on working ability and the whole working organization, as well. Thus, burnout syndrome is associated with the already mentioned absenteeism and presentism, but also with reduced work pleasure and migration of teachers, as well as the abandonment of the profession. People with the burnout syndrome establish poor relationships with colleagues and in this way distract the performance of the work tasks $(1,42)$. All this leads to the increased economic burden in the country. In Germany, the burnout syndrome is considered to be one of the leading causes of an increased number of premature pensions (43), and according to data in Norway, about $15 \%$ of absences are due to the burnout syndrome, with the annual costs of this disorder amounted to 1.7 billion euros in 2005 (23). It is estimated that companies lose up to $\$ 60$ billion each year due to reduced employee productivity and an 
additional $10 \%$ of their earnings due to incapacity for work related to stress (44).

\section{Conclusion}

Based on the presented results of the previous resear$\mathrm{ch}$, it can be concluded that the burnout syndrome of educational workers is a phenomenon that leaves significant consequences on teachers as individuals, on children as users, and on the community as a whole. Consequently, it represents a significant public health problem. Marić et al. have suggested development of regular screening programs for burnout syndrome, which could be implemented before the beginning, in the middle and at the end of the school year (45). Further research is inevitable in order to better understand this phenomenon. By identifying different individual and situational factors that contribute to the stress levels at workplace, it will be easier to form targeted interventions in order to reduce exposure to stress at work and reduce the prevalence of this syndrome among teachers.

\section{References}

1. Maslach C, Schaufeli WB, Leiter MP. Job Burnout. Annu Rev Psychol. 2001;(52):397-422.

2. Schaufeli WB, Leiter MP, Maslach C. Burnout: 35 years of research and practice. Career Development International. 2008;14(3):204-20.

3. Friedman I. Burnout inTeachers. Vol. 56, Pyschotherapy in Practice. 2000. p. 595-606.

4. García-Arroyo JA, Segovia AO, Peiró JM. Meta-analytical review of teacher burnout across 36 societies: the role of national learning assessments and gender egalitarianism. Psychology \& Health. 2019;36(6):1-21.

5. Salvagioni DAJ, Melanda FN, Mesas AE, González AD, Gabani FL, Andrade SM de. Physical, psychological and occupational consequences of job burnout: A systematic review of prospective studies. van Wouwe JP, editor. PLOS ONE. 2017

6. Harding S, Morris R, Gunnell D, Ford T, Hollingworth W, Tilling K, et al. Is teachers' mental health and wellbeing associated with students' mental health and wellbeing? Journal of Affective Disorders. 2019;242:180-7.

7. Bernotaite L, Malinauskiene V. Workplace bullying and mental health among teachers in relation to psychosocial job characteristics and burnout. International Journal of Occupational Medicine and Environmental Health. 2017;30(4):629-40.

8. Arvidsson I, Håkansson C, Karlson B, Björk J, Persson R. Burnout among Swedish school teachers - a cross-sectional analysis. BMC Public Health. 2016;16(823).

9. Bauer J, Stamm ÆA, Virnich ÆK, Wirsching ÆM. Correlation between burnout syndrome and psychological and psychosomatic symptoms among teachers. International Archives of Occupational and Environmental Health. 2006;79:199-204.

10. Greenglass ER, Burke RJ, Konarski R. The impact of social support on the development of burnout in teachers: Examination of a model. Work and Stress. 1997;11(3):267-78.

11. Mark C, Pierce B, Molloy GN. Psychological and Biographical Differences Between Secondary School Teachers Experiencing High and Low Levels of Burnout. British Journal of Educational Psychology. 1990;60(1):37-51.

12. Lau PSY, Yuen MT, Chan RMC. Do demographic characteristics make a difference to burnout among Hong Kong secondary school teachers? Social Indicators Research. 2005;71(1):491-516.

13. Schwarzer R, Schmitz GS, Tang C. Teacher burnout in Hong Kong and Germany: A cross-cultural validation of the Maslach burnout inventory. Anxiety, Stress and Coping. 2000;13(3):309-26.
14. Paleksić V, Ubović R, Popović M. Osobine ličnosti i sindrom sagorijevanja kod nastavnika osnovnih i srednjih škola. Scripta Medica. 2015;46(2):118-24.

15. Koludrović M, Jukić T, Reić Ercegovac I. Sagorijevanje Na Poslu Kod Učitelja Razredne I Predmetne Nastave Te Srednjoškolskih Nastavnika. Život I Škola. 2009;22:235-49.

16. Kuzijev J. Uloga odabira učiteljske profesije i samopoštovanja u garorijevanju učitelja u osnovnoj školi. Andragoški glasnik. 2013;17(2010):125-44.

17. Mojsa-Kaja J, Golonka K, Marek T. Job burnout and engagement among teachers - Worklife areas and personality traits as predictors of relationships with work. International Journal of Occupational Medicine and Environmental Health. 2015;28(1):102-19.

18. Goddard R, O'Brien P, Goddard M. Work environment predictors of beginning teacher burnout. British Educational Research Journal. 2006;32(6):857-74.

19. Stansfeld S, Candy B. Psychosocial work environment and mental health - A meta-analytic review. Scandinavian Journal of Work, Environment and Health. 2006;32(6):443-62.

20. Hakanen JJ, Bakker AB, Schaufeli WB. Burnout and work engagement among teachers. Journal of School Psychology. 2006;43(6):495-513.

21. Burke RJ, Greenglass E. Work Stress, Role Conflict, Social Support, and Psychological Burnout among Teachers. Psychological Reports. 1993;73(2):371-80.

22. Santavirta N, Solovieva $\mathrm{S}$, Theorell $\mathrm{T}$. The association between job strain and emotional exhaustion in a cohort of 1,028 Finnish teachers. British Journal of Educational Psychology. 2007;77(1):213-28.

23. Lastovkova A, Carder M, Rasmussen HM, Sjoberg L, de Groene GJ, Sauni R, et al. Burnout syndrome as an occupational disease in the European Union: an exploratory study. Industrial Health. 2017;(56):160-5.

24. Xanthopoulou D, Bakker AB, Demerouti E, Schaufeli WB. Reciprocal relationships between job resources, personal resources, and work engagement. Journal of Vocational Behaviour. 2009;74(3):235-44.

25. Schaufeli WB, Bakker AB. Job demands, job resources, and their relationship with burnout and engagement: a multi-sample study. Journal of Organizational Behaviour. 2004;25:1-18.

26. Unterbrink T, Hack A, Pfeifer R, Buhl-Griehaber V, Müller $\mathrm{U}$, Wesche $\mathrm{H}$, et al. Burnout and effort-reward-imbalance in a sample of 949 German teachers. International Archives of Occupational and Environmental Health. 2007;80(5):433-41.

27. Sale JEM, Kerr MS. The psychometric properties of Karasek's demand and control scales within a single sector: Data from a large teaching hospital. International Archives of Occupational and Environmental Health. 2002;75(3):145-52.

28. Antoniou A-S, Ploumpi A, Ntalla M. Occupational Stress and Professional Burnout in Teachers of Primary and Secondary Education: The Role of Coping Strategies. Psychology. 2013;04(03):349-55.

29. Friedman I. High and low burnout schools culture aspects of teacher burnout. Jouurnal of Educational Research. 1991;84(6):325-33.

30. Schwarzer R, Hallum S. Perceived teacher self-efficacy as a predictor of job stress and burnout: Mediation analyses. Applied Psychology. 2008;57(SUPPL. 1):152-71.

31. Kokkinos CM. Job stressors, personality and burnout in primary school teachers. British Journal of Educational Psychology. 2007;77(1):229-43.

32. Rey L, Extremera N, Pena M. Emotional competence relating to perceived stress and burnout in Spanish teachers: a mediator model. PeerJ. 2016;4:e2087.

33. Spector PE, Connell BJO. The contribution of personality traits, negative affectivity, locus of control and Type A to the subsequent reports of job stressors and job strains. Journal of Occupational and Organizational Psychology. 1994;(67):1-11.

34. Antoniou AS, Polychroni F, Vlachakis AN. Gender and age differences in occupational stress and professional burnout 
between primary and high-school teachers in Greece. Journal of Managerial Psychology. 2006;21(7):682-90.

35. Martocchio JJ, O'Leary AM. Sex Differences in Occupational Stress: A Meta-Analytic Review. Journal of Applied Psychology. 1989;74(3):495-501.

36. Purvanova RK, Muros JP. Gender differences in burnout: A meta-analysis. Journal of Vocational Behavior [Internet]. 2010;77:168-85.

37. Russell DW, Altmaier E, Van Velzen D. Job-Related Stress, Social Support, and Burnout Among Classroom Teachers. Journal of Applied Psychology. 1987;72(2):269-74.

38. Wang Y, Ramos A, Wu H, Liu L, Yang X, Wang J, et al. Relationship between occupational stress and burnout among Chinese teachers: a cross-sectional survey in Liaoning, China. International Archives of Occupational and Environmental Health. 2015;88(5):589-97.

39. Greenglass ER, Burke RJ. Work and Family Precursors of Burnout in Teachers: Sex Differences I. Sex Roles. 1988;18(3):215-29.

40. Kirsi A. The relationship between job-related burnout and depressive disorders-results from the Finnish Health 2000 Study. Journal of Affective Disorders. 2015;88:55-62.
41. Ahola K, Honkonen T, Pirkola S, Isometsä E, Kalimo R, Nykyri $\mathrm{E}$, et al. Alcohol dependence in relation to burnout among the Finnish working population. Addiction. 2006;101(10):1438-43.

42. Ryan S V, Ed M, Embse NP Von Der, Pendergast LL, Saeki E, Segool N, et al. Leaving the teaching profession: The role of teacher stress and educational accountability policies on turnover intent. Teaching and Teacher Education. 2017;66:1-11.

43. Goetz K, Loew T, Hornung R, Cojocaru L, Lahmann C, Tritt K. Primary prevention programme for burnout-endangered teachers: Follow-up effectiveness of a combined group and individual intervention of afa breathing therapy. Evidence-based Complementary and Alternative Medicine. 2013;2013.

44. Anderson VL. The effects of meditation on teacher perceived occupational stress and trait anxiety. Dissertation abstracts international. 1996;57(1):934.

45. Marić N, Mandić-Rajčević S, Maksimović N, Bulat $\mathrm{P}$. Factors Associated with Burnout Syndrome in Primary and Secondary School Teachers in the Republic of Srpska (Bosnia and Herzegovina). International Journal of Environmental Research and Public Health. 2020;17(3595):1-13. 